\title{
Occupational Health and Safety of Commercial Motorcyclists in Obollo-Afor: An Adult Education Approach
}

\author{
Matthias U Agboeze ${ }^{1}$, Ruphina U. Nwachukwu ${ }^{1}$, Michael O. Ugwueze ${ }^{1}$ \& Maryrose N. Agboeze ${ }^{1}$ \\ ${ }^{1}$ Department of Adult Education and Extra-Mural Studies, University of Nigeria, Nsukka, Nigeria \\ Correspondence: Ruphina U. Nwachukwu, Department of Adult Education and Extra-Mural Studies, University \\ of Nigeria, Nsukka, Nigeria. Tel: 234-701-537-8097. E-mail: ruphina.nwachukwu@unn.edu.ng
}

Received: April 10, 2020 Accepted: June 4, 2020 Online Published: June 26, 2020

doi:10.5539/gjhs.v12n9p24 URL: https://doi.org/10.5539/gjhs.v12n9p24

\begin{abstract}
This study investigated Federal Road Safety Commission (FRSC) public education programme as an adult education approach for improving the health and safety conditions of commercial motorcyclists in Obollo-afor, Nigeria. A descriptive survey research design was used for the study. The population of the study comprised of the four hundred and sixty four (464) commercial motorcyclists and FRSC staff, out of which 108 commercial motorcyclists and the 10 Federal Road Safety Corps staff were sampled using purposive sampling technique. The findings of the study include that FRSC public education programme to a high extent can help in the reduction of accidents and injuries involving commercial motorcyclists. The study recommended that FRSC officials should organize regular road safety awareness campaign on the streets, schools, churches and market square.
\end{abstract}

Keywords: adult education, commercial motorcyclists, occupational health and safety

\section{Introduction}

The Occupational health and safety of workers is relevant to their performance and output. Occupational health and safety is the science of anticipating, recognizing, evaluating and controlling various hazards arising from the work environment which could challenge the health and well-being of workers while also taking into account the possible impact on the surrounding communities and the general environment (Alli, 2008). Occupational health and safety is designed to eradicate or reduce the injuries sustained in work related environments; however, irrespective of the commendable developments associated with occupational health and safety, several forms of accidents still trouble workers in their work environments (Vayrynem, Hakkinen, \& Nisknen, 2015).

These accidents could lead to workers getting severely injured, working facilities or equipments getting damaged thereby resulting to low productivity (Fernandez, Montes, \& Vazquez, 2009). More so, statistics from International Labor Organization (ILO) states that about 2.3 million people lose their lives each year as a result of accidents or illness related to their work environment; also, there exists about 264 million non-fatal work related hazards yearly leading to illness of workers (ILO, 2019). Accidents and injuries associated with motorcyclists make up a high proportion of occupational health and safety challenges in developing countries such as Nigeria (Shaker, Eldesouky, Hasan, \& Bayomy, 2014).

A commercial motorcyclist is an individual who carries people and/or goods from one place to another for a stipulated price using a motorcycle. Commercial motorcycle or Okada as it is popularly called in most part of Nigeria is one of the most common means of transportation in Nigeria (Sanusi \& Emmelin, 2015). However, despite the various benefits of motorcycle as an easily accessible means of transportation, commercial motorcyclists still contribute to the high rate of work related accidents (Hung \& Huyen, 2011; Morenikeji \& Umaru, 2012; Oster \& Strong, 2013). The high rate of motorcyclist related accidents is majorly as a result of inadequate knowledge or awareness of the commercial motorcyclists on the various traffic and road safety measures; this has led to the disregard for traffic regulations and subsequently accidents and injuries (Johnson \& Adebayo, 2011; Osinowo, Kunle-Olowu, \& Osinowo, 2011a). However, sensitization and enlightenment of youths and adults through adult education programmes could go a long way in reducing the rate of accidents and injuries related to commercial motorcyclists.

Adult education could help workers become aware of and to avoid causes of accidents in their work environment. Adult education is a form of organized learning within or outside the formal school system which is designed for 
adults to enable them acquire new knowledge and skill or to update their previous knowledge (Halilu, 2018). Adult education programmes has the capacity of improving the attitude and behavior of youths and adults; adult education improves the ability of youths and adults to think critically and to take responsibility for all their actions (Maclean, 2009). The Federal Road Safety Corps (FRSC) public education programme is an adult education programme designed to sensitize road users, including the commercial motorcyclists on the rules and regulations to adhere to in order to ensure the reduction of accidents and injuries on the road (Adams \& Toyin, 2012)

The inadequate knowledge of commercial motorcyclists on the various road safety rules and regulations necessitated the idea of FRSC public education programme. FRSC public education programme is a necessary approach towards ensuring the health and safety of commercial motorcyclists and other road users; traffic and road safety education imbibes in the motorcyclists the necessary knowledge and skills to enable them operate a safer work environment and reduce the risk of accidents in their work environment (Raftery \& Wundersitz, 2011). Therefore, FRSC public education programmeas an adult education approach to safer road related work environment helps to prevent commercial motorcyclists from death or injury on the traffic environment.

In Obollo-afor Nigeria, the number of commercial motorcyclists is on the increase. This increase is commonly attributed to the high level of unemployment among the youths in the region (Osinowo, Kunle-Olowu, \& Osinowo, 2011b). Almost on a daily basis, a case of traffic accident and injuries involving a commercial motorcyclist is heard of in Obollo-afor Nigeria. This is largely due to the fact that most of the motorcyclists do not undergo adequate training before embarking on the motorcycle transport business, they do not pay heed to traffic regulations; majority of the commercial motorcyclists carry more than the stipulated one passenger at a time, they over speed and do not wear helmets (M. Odo, Personal Communication, March 12, 2019). Measures such as increment of law enforcement agencies on the high ways and mapping out of strict punishment for road safety rule offenders have been put in place to curb the rate of accident and injuries involving commercial motorcyclists. However, the accidents keep occurring; thereby challenging the health and safety of commercial motorcyclists in Obollo-afor. Therefore, this study seeks to assess adult education approach for improving the health and safety conditions of commercial motorcyclists in Obollo-afor, Nigeria. Specifically, the study sought to: Ascertain the factors responsible for accidents and injuries involving commercial motorcyclists in Obollo-afor, Nigeria; investigate the riding habits of commercial motorcyclists in Obollo-afor, Nigeria and determine the extent to which FRSC public education programme help in the reduction of accidents and injuries involving commercial motorcyclists in Obollo-afor, Nigeria.

\section{Methods}

\subsection{Study Design and Setting}

A descriptive survey research design was used for the study. The descriptive survey research design was used because the researchers were interested in the assessment of the educational strategies for improving the health and safety condition of commercial motorcyclists in Obollo-afor, Nigeria. Descriptive survey studies aim to gather data on the characteristics, features or facts about a given population and describing these data in a systematic manner so as to achieve a research objective (Nworgu, 2015).

Obollo-afor is a semi-urban town found in Udenu local government area of Enugu State, Nigeria. Obollo-afor shares boundary with Enugu Ezike, Imilike, Obollo-etiti and Iheakpu. Majority of people in Obollo-afor are agriculturists; they specialize in growing cassava, yam, cocoyam, cashew and palm nut trees. Majority of the community members are Christians while few others practice African traditional religion.

\subsection{Population and Sample}

The population of this study consists of the four hundred and twelve (412) commercial motorcyclists registered in 12 different commercial motorcyclist unions in Obollo-afor and the fifty two (52) staff of Federal Road Safety Corps, Obollo-afor command; making up a population of four hundred and sixty four (464) for the study. Purposive sampling technique was used to sample 108 commercial motorcyclists who reportedly had been involved in motorcycle accident in Obollo-afor and the 10 most senior staff of Federal Road Safety Corps, Obollo-aforcommand; making up the one hundred and eighteen (118) respondents for the study.

\subsection{Data Collection}

A structured questionnaire made up of 22 items was designed by the researchers to obtain data on the factors responsible for accidents and injuries involving commercial motorcyclists in Obollo-afor, Nigeria, the riding habits of commercial motorcyclists in Obollo-afor, Nigeria and the extent to which FRSC public education programme could help in the reduction of accidents and injuries involving commercial motorcyclists in Obollo-afor, Nigeria. 
The questionnaire was designed in English language as it is a language clearly understood by majority of the people in the study area. The questionnaire was face validated by 2 experts from department of adult education, University of Nigeria, Nsukka and one expert from department of science education (measurement and evaluation unit) of the same university. Cronbach alpha technique was used to determine the internal consistency of the questionnaire items and the reliability coefficient of 0.85 was obtained.

The structured questionnaire was administered to 108 commercial motorcyclists by the researchers on April 28, 2019 during the quarterly meeting of the commercial motorcyclists in Obollo-afor, Nigeria; it was also administered to 10 most senior staff of Federal Road Safety Corps, Obollo-afor command in their offices during office hours between May $13^{\text {th }}-16^{\text {th }}, 2019$.

\subsection{Data Analysis}

Data collected was analyzed using descriptive statistics such as frequency, mean and standard deviation.

\section{Results}

Table 1. Mean analysis of the ratings of commercial motorcyclists and FRSC Staff on the factors responsible for accidents and injuries involving commercial motorcyclists

\begin{tabular}{lllllc}
\hline S/NItem Statement & Group & N & Mean & Std. Deviation & Decision \\
\hline 1. Use of alcohol, drugs or psychoactive substance & Commercial Motorcyclists & 108 & 3.65 & .62 & Agree \\
& FRSC Staff & 10 & 3.80 & .42 & Agree \\
\hline 2. Untrained riding & Commercial Motorcyclists & 108 & 3.19 & 1.27 & Agree \\
& FRSC Staff & 10 & 3.40 & 1.26 & Agree \\
\hline 3. Over speeding & Commercial Motorcyclists & 108 & 3.65 & .62 & Agree \\
& FRSC Staff & 10 & 3.80 & .42 & Agree \\
\hline 4. Poor motorcycle maintenance & Commercial Motorcyclists & 108 & 3.02 & 1.21 & Agree \\
& FRSC Staff & 10 & 3.20 & 1.22 & Agree \\
\hline 5. Negligence for use of road signs & Commercial Motorcyclists & 108 & 3.40 & .76 & Agree \\
& FRSC Staff & 10 & 3.40 & .84 & Agree \\
\hline 6. Disregard for use of personal protective equipmentCommercial Motorcyclists & 108 & 3.50 & .57 & Agree \\
(e.g. helmet) & FRSC Staff & 10 & 3.60 & .51 & Agree \\
\hline 7. Overloading the motorcycle & Commercial Motorcyclists & 108 & 3.33 & .79 & Agree \\
\hline Overall Mean & FRSC Staff & 10 & 3.40 & .84 & Agree \\
\hline
\end{tabular}

Table 1 shows that the mean ratings of commercial motorcyclists and FRSC Staff on items 1 to 7 are more than the 2.50 criterion mean. This means that both commercial motorcyclists and FRSC Staff agreed that: use of alcohol, drugs or psychoactive substance; untrained riding; over speeding; poor motorcycle maintenance; negligence for use of road signs; disregard for use of personal protective equipment (e.g. helmet) and overloading the motorcycle are the factors responsible for accidents and injuries involving commercial motorcyclists. 
Table 2. Percentage analysis of riding habit of commercial motorcyclists in Obollo-Afor, Nigeria

\begin{tabular}{llll}
\hline S/N & Item Statement & \% Yes & \%No \\
\hline 1. & Make use of helmet while riding a motorcycle & 27.1 & 72.9 \\
2. & Drink alcohol before riding a motorcycle & 83.1 & 16.9 \\
3. & Speed above $100 \mathrm{~km} / \mathrm{hr}$ & 72.9 & 27.1 \\
4. & Carry more than one passenger at a time & 83.1 & 16.9 \\
5. & Obey road traffic signs & 42.0 & 58.0 \\
6. & Have driving license & 43.3 & 56.7 \\
7. & Make good use of side mirrors & 48.3 & 51.7 \\
8. & Overtake recklessly & 81.4 & 18.6 \\
\hline
\end{tabular}

Table 2 shows that the riding habits of commercial motorcycle in Obollo-Afor include: riding motorcycle without helmet, drinking alcohol before riding a motorcycle, applying speed above $100 \mathrm{~km} / \mathrm{hr}$, carrying more than one passenger at a time, not obeying the driving traffic signs, not having driving license, not making good use of side mirrors and overtaking recklessly.

Table 3. Mean analysis of the ratings of commercial motorcyclists and FRSC Staffontheextent to which FRSC public education programme help in the reduction of accidents and injuries involving commercial motorcyclists

\begin{tabular}{|c|c|c|c|c|c|}
\hline $\mathrm{S} / \mathrm{N}$ & Item Statement & $\mathrm{N}$ & Mean & $\begin{array}{l}\text { Std. } \\
\text { Deviation }\end{array}$ & Decision \\
\hline \multirow[t]{2}{*}{1.} & \multirow{2}{*}{$\begin{array}{l}\text { Educates the commercial motorcyclists on various Commercial Motorcyclists } \\
\text { road signs }\end{array}$} & 108 & 2.89 & .76 & $\mathrm{HE}$ \\
\hline & & 10 & 3.10 & .56 & $\mathrm{HE}$ \\
\hline \multirow[t]{2}{*}{2.} & \multirow{2}{*}{$\begin{array}{l}\text { Sensitizes the commercial motorcyclists on the Commercial Motorcyclists } \\
\text { appropriate use of helmet and other proactive gears FRSC Staff }\end{array}$} & 108 & 3.02 & .93 & $\mathrm{HE}$ \\
\hline & & 10 & 3.20 & .63 & $\mathrm{HE}$ \\
\hline \multirow[t]{2}{*}{3.} & \multirow{2}{*}{$\begin{array}{l}\text { Trains the commercial motorcyclists on variousCommercial Motorcyclists } \\
\text { motorcycle safety precaution checks (eg. Appropriate } \\
\text { tire gauge) } \\
\text { FRSC Staff }\end{array}$} & 108 & 3.09 & .69 & $\mathrm{HE}$ \\
\hline & & 10 & 3.10 & .56 & $\mathrm{HE}$ \\
\hline \multirow[t]{2}{*}{4.} & \multirow{2}{*}{$\begin{array}{l}\text { Educates the commercial motorcyclists on various Commercial Motorcyclists } \\
\text { motorcycle maintenance tips }\end{array}$} & 108 & 3.33 & .66 & $\mathrm{HE}$ \\
\hline & & 10 & 3.30 & .48 & $\mathrm{HE}$ \\
\hline \multirow[t]{2}{*}{5.} & \multirow{2}{*}{$\begin{array}{l}\text { Highlights the dangers of disobedience to safety roadCommercial Motorcyclists } \\
\text { signs } \\
\text { FRSC Staff }\end{array}$} & 108 & 3.11 & .78 & $\mathrm{HE}$ \\
\hline & & 10 & 3.40 & .51 & $\mathrm{HE}$ \\
\hline \multirow[t]{2}{*}{6.} & \multirow{2}{*}{$\begin{array}{l}\text { Creates awareness on the appropriate time andCommercial Motorcyclists } \\
\text { manner of overtaking vehicles } \\
\text { FRSC Staff }\end{array}$} & 108 & 3.50 & .50 & VHE \\
\hline & & 10 & 3.70 & .48 & VHE \\
\hline \multirow[t]{4}{*}{7.} & \multirow{2}{*}{ Introduces speed control mechanism } & 108 & 3.50 & .57 & VHE \\
\hline & & 10 & 3.50 & .52 & VHE \\
\hline & \multirow{2}{*}{ Overall Mean } & 108 & 3.21 & .38 & HE \\
\hline & & 10 & 3.32 & .37 & HE \\
\hline
\end{tabular}

Table 3 reveals that the overall mean ratings of commercial motorcyclists and FRSC Staff on the extent to which FRSC public education programme help in the reduction of accidents and injuries involving commercial motorcyclists are within the mean range of 2.50 and 3.49. This indicates that FRSC public education programme to a high extent can help in the reduction of accidents and injuries involving commercial motorcyclists.

\section{Discussion}

The findings of research question one revealed that the factors responsible for accidents and injuries involving commercial motorcyclists in Obollo-Afor, Nigeria include: use of alcohol; drugs or psychoactive substance; 
untrained riding; over speeding; poor motorcycle maintenance; negligence for use of road signs; disregard for use of personal protective equipment (e.g. helmet) and overloading the motorcycle are the factors responsible for accidents and injuries involving commercial motorcyclists. This finding is related to the findings of Nwadiaro, Ekwe, Akpayak and Shitta (2011); Sufyan and Ahmad (2012) which disclosed that high rate of motorcycle accidents in Nigeria is attributed to lack of adequate training of motorcyclists, ignorance and negligence to road safety regulations, and bad road system.

In addition, findings from research question two revealed that the riding habits of commercial motorcycle in Obollo-Afor include: riding motorcycle without helmet, making use of alcohol before riding a motorcycle, applying speed above $100 \mathrm{~km} / \mathrm{hr}$, carrying more than one passenger at a time, not obeying the driving traffic signs among others. This agrees with the assertion of S. Eze (personal communication, March 29, 2019) who stated that the high rate of accidents involving commercial motorcyclists is largely due to the fact that most of the motorcyclists do not undergo adequate training before embarking on the motorcycle business, they do not pay heed to traffic regulations; majority of the commercial motorcyclists carry more than the stipulated one passenger at a time, they over speed and do not wear helmets.

Finally, findings from research question three revealed that FRSC public education programme to a high extent can help in the reduction of accidents and injuries involving commercial motorcyclists as it; educates the commercial motorcyclists on various road signs, sensitizes the commercial motorcyclists on the appropriate use of helmet and other proactive gears, trains the commercial motorcyclists on various motorcycle safety precaution checks (eg. Appropriate tire gauge), educates the commercial motorcyclists on various motorcycle maintenance tips, highlights the dangers of disobedience to safety road signs, creates awareness on the appropriate time and manner of overtaking vehicles and introduces speed control mechanism. This agrees with Adams and Toyin (2012) who stated that FRSC public education programme changed the road behaviours of commercial road users; they stopped overtaking recklessly, over speeding and overloading of their machine among others.

\section{Conclusion}

Based on findings of this study, it can be concluded that the behavior and driving habits of commercial motorcyclists are the major causes of accidents and injuries involving commercial motorcyclist. However, FRSC public education to a high extent helps in changing the behavior and driving habits of commercial motorcyclists thereby reducing accidents and injuries involving commercial motorcyclist.

\section{Recommendations}

The following recommendations were made to help in reducing the rate of accidents and injuries involving commercial motorcyclists.

- The government should ensure that they construct durable speed breaker in all major roads.

- The FRSC officials on duty should use breathe testing devices to detect blood alcohol content of motorcyclists and drivers.

- The FRSC officials should organize regular road safety awareness campaign on the streets, schools, churches and market square.

\section{Competing Interests Statement}

The authors declare that there are no competing or potential conflicts of interest.

\section{References}

Adams, O. U., \& Toyin, F. A. (2012). The Effectiveness of FRSC public education programme on drivers' road traffic habit in Lagos and Oyo States of Nigeria. British Journal of Arts and Social Sciences, 6(1), 129-139.

Alli, B. O. (2008). Fundamental principles of occupational health and safety. International Labour Office Geneva: ILO.

Fernandez-Muniz, B., Montes-Peon, J. M., \& Vazquez-Ordas, C. J. (2009). Relation between occupational safety management and firm performance. SafSci Journal, 47(3), 980-91. https://doi.org/10.1016/j.ssci.2008.10.022

Halilu, A. (2018). Adult Education and Illiteracy Eradication. In A. N. Ugwu, \& O. F. Mbalisi, (Eds.), Contemporary issues in Adult education: An African Perspective (118-131). Port Harcourt. Pearl publishers international ltd.

Hung, K. V., \& Huyen, L. T. (2011). Education influence in traffic safety: A Case Study in Vietnam. IATSS 
Research, 34, 87-93. https://doi.org/10.1016/j.iatssr.2011.01.004

International Labour Organization. Safety and health at work: a vision for sustainable prevention. (2019). Retrieved from http://www.ilo.org/wcmsp5/groups/public/-ed_protect/-protrav/-safework/documents/ publication/wcms_301214.pdf

Johnson, O. E., \& Adebayo, A. M. (2011). Effect of safety education on knowledge of and compliance with road safety signs among commercial motorcyclists in Uyo, Southern Nigeria. Ghana Medical Journal, 45(3), 89-96.

Mclean, P. A. (2009). Determining the role of adult education in the process for building the culture of sustainable development. Florida: Atlantic University, Boca Raton, Florida.

Morenikeji, W., \& Umaru, E. (2012). Flying without navigational aids - The case of commercial motorcyclists in Minna, Nigeria. Transportation Research Part F: Traffic Psychology and Behaviour, 15(3), 311-318. https://doi.org/10.1016/j.trf.2012.02.003

Nwadairo, H. C., Ekwe, K. K., Akpayak, I. C., \& Shitta, H. (2011). Motorcycle injuries in North-Central Nigeria. Nigerian Journal of Clinical Practices, 14(2), 186-189. https://doi.org/10.4103/1119-3077.84012

Nworgu, B.G. (2015). Educational research: Basic issues and methodology. Nsukka; University trust publishers.

Osinowo, H. O., Kunle-Olowu, O. A., \& Osinowo, O. A. (2011). Socio Economic impacts of the ban on commercial motorcycle taxis (Okada) in Port Harcourt metropolis, Rivers State. Niger Delta Afri $J H \&$ E., $8(2), 1-11$.

Osinowo, O. A., Kunle-Olowu, A. O., \& Osinowo, H. O. (2011). Psycho-social determinants of road traffic accidents among commercial motorcycle (Okada) riders in a semiurban area of Bayelsa State. Port Harcourt Medical Journal, 5(3), 312-324.

Oster, C. V., \& Strong, J. S. (2013). Analyzing road safety in the United States. Research in transport economics 43, 98-111. https://doi.org/10.1016/j.retrec.2012.12.005

Raftery, S. J., \& Wundersitz, L. N. (2011). The efficacy of road safety education in school.A review of current approaches. Center for Automotive Safety Research (CASR) Technical Report Series. University of Adelaide, Australia.

Sanusi, A., \& Emmelin, M. (2015). Commercial motorcycle drivers' perceptions of risk and road safety in urban Nigeria: an explorative study. International Journal of Injury Control and Safety Promotion, 22(4), 328-339. https://doi.org/10.1080/17457300.2014.909499

Shaker, R. H., Eldesouky, R. S., Hasan, O. M., \& Bayomy, H. (2014). Motorcycle crashes: attitudes of the motorcyclists regarding riders??? Experience and Safety Measures. Journal of Community Health. 39(6), 1222-30. https://doi.org/10.1007/s10900-014-9883-1

Sufyan, M. B., \& Ahmad, S. M. (2012): Knowledge, attitude and compliance with safety protective devices among commercial motorcyclists in Tudun-Wada Zaria, North-Western Nigeria. Annals of Nigerian Medicine, 6(2), 80-86. https://doi.org/10.4103/0331-3131.108126

Väyrynen, S., Hakkinen, K., \& Niskanen, T. (2015). Integrated occupational safety and health management solutions and industrial cases (pp. 7-15). Switzerland: Springer. https://doi.org/10.1007/978-3-319-13180-1

\section{Copyrights}

Copyright for this article is retained by the author(s), with first publication rights granted to the journal.

This is an open-access article distributed under the terms and conditions of the Creative Commons Attribution license (http://creativecommons.org/licenses/by/4.0/). 